\title{
MEDICAL TREATMENT AS AN ALTERNATIVE TO THORACOPLASTY IN PULMONARY TUBERCULOSIS
}

\author{
BY
}

\author{
P. G. ARBLASTER, I. R. McWHINNEY, R. ABBEY SMITH, AND K. W. CROSS \\ From King Edward VII Memorial Chest Hospital, Warwick, and the Department of Medical \\ Statistics, University of Birmingham
}

(RECEIVED FOR PUBLICATION APRIL 12, 1958)

The object of this investigation was to determine the results of treatment in a group of patients with pulmonary tuberculosis suitable for thoracoplasty but on whom no operation was performed.

Before the introduction of antibacterial drugs an evaluation of thoracoplasty was made by Refsum (1951) in a retrospective analysis of 106 cases diagnosed between 1921 and 1928, who, although suitable for thoracoplasty, did not have an operation. This series was compared with a group of similar patients who had thoracoplasty. At the end of 10 years, the mortality of operated patients was less than half that of patients who did not have the operation.

There will be general agreement that antibacterial drugs have greatly improved the results of both medical and surgical care of pulmonary tuberculosis. However, there have been no recent reports comparing the results of medical care with those of thoracoplasty.

Gough, Barlow, Holmes Sellors, and Thompson (1957) analysed the results in 231 consecutive patients submitted to thoracoplasty between 1947 and 1949. At the end of the observation period, $82 \%$ were quiescent and $14 \%$ were dead. Price Thomas (1952) reported an early mortality from thoracoplasty of $10.6 \%$ and an additional late mortality of $10 \%$. A review of thoracoplasty operations in Birmingham during 1955 by Singh and Smith (1957) revealed an early mortality of $2.5 \%$. Bickford, Edwards, Esplen, Gifford, Thomas, and Waddington (1957) have reported similar results following pulmonary resection in patients operated upon between 1947 and 1951 ; their total mortality was $5.3 \%$ and an additional $7.0 \%$ were either disabled or had active tuberculosis.

\section{Method of Case Selection}

South Warwickshire is semi-rural and has a population of 230,000 . There were 1,183 notified pulmonary tuberculosis patients between 1946 and 1955 , and the records of 1,007 were traced and examined. Two hundred and eighteen patients had $\overrightarrow{\vec{A}}$ left the area, and 125 of these were traced. There were 213 deaths and the records of 174 of these were scrutinized. Untraced notes were confined to patients who died before 1951. All records and radiographs were examined in strict chronological order by a panel consisting of a surgeon, a physician, and a research registrar, with the object of selecting those patients who at any time had satisfied the criteria of suitability for thoracoplasty.

To preclude bias the final state of the patient was not known at first scrutiny. The criteria for selection were those currently accepted at the date of each radiograph. During the period of review these criteria had changed following the introduction of chemotherapy and for other less definite reasons based upon the personal experiences of the panel. However, the radiographic criteria for suitability for operation adopted by the panel may be outlined as:

(a) Patients with unilateral cavitation confirmed, where necessary, by tomography.

(b) Patients with substantial unilateral disease changing in appearance over six months.

(c) Patients with bilateral disease and cavitation at one apex.

(d) Patients with persistent round foci greater than $2 \mathrm{~cm}$. in diameter were excluded.

After the radiographic selection further information 윽 was obtained from the case records. Patients under $\frac{D}{2}$ 18 and over 60 years of age, those with a record of severe dyspnoea on exertion (two cases), and those $\mathrm{N}$ with radiographic or clinical evidence of severe $\sigma$ emphysema (three cases) were excluded. Mental N hospital patients certified as unfit for operation were $N$ also excluded. Patients found to be sputum negative $\sigma$ or whose radiographs showed no change at final< assessment were re-checked for confirmation of $\stackrel{\circ}{=}$

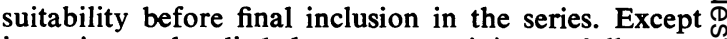
in patients who died there was a minimum follow-up? of one year.

\section{Cases Selected as Suitable for THORACOPLASTY}

Two hundred and fifty-nine patients were selected as suitable for thoracoplasty, that is, $25 \%$ of notified pulmonary tuberculosis patients. 
TABLE I

TREATMENT AND EXTENT OF DISEASE IN 259 PATIENTS SUITABLE FOR THORACOPLASTY

\begin{tabular}{|c|c|c|c|c|c|c|c|}
\hline \multirow{3}{*}{\multicolumn{3}{|c|}{$\begin{array}{l}\text { Extent of Disease by } \\
\text { Classification of } \\
\text { Foster-Carter and } \\
\text { others (1952) }\end{array}$}} & \multicolumn{4}{|c|}{ Method of Treatment } & \multirow{2}{*}{ Total } \\
\hline & & & \multirow{2}{*}{$\frac{\text { Operation }}{1946-55}$} & \multicolumn{3}{|c|}{ Medical Care Only } & \\
\hline & & & & $1946-51$ & $1952-55$ & All Cases 1946-55 & $1946-55$ \\
\hline $\begin{array}{cl}\text { Class } & \text { I } \\
\text {,, } & \text { II } \\
, & \text { III }\end{array}$ & $\begin{array}{l}\ldots \\
\ldots \\
\ldots\end{array}$ & $\begin{array}{l}\cdots \\
\cdots \\
\cdots\end{array}$ & $\begin{array}{rr}19 & (26 \%) \\
51 & (71 \%) \\
2 & (3 \%)\end{array}$ & $\begin{array}{ll}30 & (32 \%) \\
54 & (57 \%) \\
10 & (11 \%)\end{array}$ & $\begin{array}{l}35(38 \%) \\
44(47 \%) \\
14(15 \%)\end{array}$ & $\begin{array}{ll}65 & (35 \%) \\
98 & (53 \%) \\
24 & (12 \%)\end{array}$ & $\begin{aligned} 84 & (58 \%) \\
149 & (32 \%) \\
26 & (10 \%)\end{aligned}$ \\
\hline & Total & . & $72(100 \%)$ & $94(100 \%)$ & $93(100 \%)$ & $187(100 \%)$ & $259(100 \%)$ \\
\hline
\end{tabular}

TABLE II

COMPARATIVE INCIDENCE OF UNILATERAL AND BILATERAL DISEASE IN MEDICAL CARE AND THORACOPLASTY PATIENTS

\begin{tabular}{|c|c|c|c|c|c|c|c|}
\hline \multirow{2}{*}{ Year } & \multicolumn{2}{|c|}{ Unilateral Disease } & \multicolumn{2}{|c|}{ Bilateral Disease } & \multicolumn{2}{|c|}{ Total } & \multirow{2}{*}{ Total } \\
\hline & Medical Care & Thoracoplasty & Medical Care & Thoracoplasty & Medical Care & Thoracoplasty & \\
\hline $\begin{array}{l}1946-51 \\
1952-55\end{array}$ & $\begin{array}{l}54(58 \%) \\
69(74 \%)\end{array}$ & $\begin{array}{l}28(74 \%) \\
25(74 \%)\end{array}$ & $\begin{array}{l}40(42 \%) \\
24(26 \%)\end{array}$ & $\begin{array}{r}10(26 \%) \\
9(26 \%)\end{array}$ & $\begin{array}{l}94 \\
93\end{array}$ & $\begin{array}{l}38 \\
34\end{array}$ & $\begin{array}{l}132 \\
127\end{array}$ \\
\hline Total (1946-55) & $123(66 \%)$ & $53(74 \%)$ & $64(34 \%)$ & $19(26 \%)$ & 187 & 72 & 259 \\
\hline
\end{tabular}

was found that 72 of these patients subsequently had an operation and that 174 did not. Thirteen patients had medical care for more than one year after suitability for thoracoplasty, but finally had an operation. They were included in the medically treated group, and their condition immediately before operation was regarded as the result of medical treatment. There was thus a total of 187 patients who form the subject of this review.

We were surprised to find that only $28 \%$ of the 259 patients considered suitable for thoracoplasty had had an operation. This figure is explained by the length of the surgical waitinglist at the relevant times, the availability of thoracic surgery, refusal of operation, change of domicile in a small number of cases, and a tendency, especially since the introduction of chemotherapy, to observe rather than to operate.

\section{Extent of Disease in Cases Suitable FOR THORACOPLASTY}

The extent of disease and method of treatment in the 259 cases selected as suitable for thoracoplasty are shown in Table I. The disease classification is that suggested by Foster-Carter, Myers, Goddard, Young, and Benjamin (1952): Class I comprises patients with not more than one zone in one lung involved; Class II includes those patients with unilateral or bilateral disease involving two or three zones; Class III covers the remaining patients, all of whom had bilateral disease affecting four or more zones.
Table II shows the proportions with unilateral and with bilateral disease, and Table III the proportions with cavitation and the proportions with positive sputum or laryngeal swab. To

TABLE III

COMPARATIVE INCIDENCE OF POSITIVE SPUTUM AND CAVITATION IN MEDICAL CARE AND THORACOPLASTY PATIENTS

\begin{tabular}{c|c|c|c|c}
\hline \multirow{2}{*}{ Year } & \multicolumn{2}{|c|}{ Cavity Presen t } & \multicolumn{2}{|c}{ Positive Sputum } \\
\cline { 2 - 6 } \cline { 5 - 6 } & $\begin{array}{c}\text { Medical } \\
\text { Care } \\
\text { Patients }\end{array}$ & $\begin{array}{c}\text { Thoraco- } \\
\text { plasty } \\
\text { Patients }\end{array}$ & $\begin{array}{c}\text { Medical } \\
\text { Care } \\
\text { Patients }\end{array}$ & $\begin{array}{c}\text { Thoraco- } \\
\text { plasty } \\
\text { Patients }\end{array}$ \\
\hline $1946-51$ & $37(39 \%)$ & $23(60 \%)$ & $68(72 \%)$ & $25(66 \%)$ \\
$1952-55$ & $52(56 \%)$ & $17(50 \%)$ & $62(67 \%)$ & $18(53 \%)$ \\
\hline Total (1946-55) & $89(48 \%)$ & $40(55 \%)$ & $130(70 \%)$ & $43(60 \%)$ \\
\hline
\end{tabular}

demonstrate the possible effect of chemotherapy. the series was arbitrarily divided into two groups ; those patients suitable for operation before and those suitable after the introduction of effective antibacterial drugs. By this division two groups of patients, 1946-51 and 1952-55, are available, and added together these are shown in the tables as $1946-55$ patients.

Tables I-III permit comparisons between the 187 medical care patients and the 72 thoracoplasty patients. A greater proportion of medical care patients $(12 \%)$ had Class III disease than operation patients $(3 \%)$ and the converse was true for Class II disease, in which $53 \%$ of medical care and $71 \%$ of operation patients were classified. As shown in Table II, the proportions with unilateral and bilateral disease did not differ 
significantly between the two groups. Table III shows that the incidence of cavities in the 187 medical care patients was similar to that in the 72 thoracoplasty patients and there was little difference in the incidence of positive sputum. It seemed reasonable to conclude that those who were treated surgically and those who were not constituted roughly comparable groups.

Having defined the extent of disease in the 187 medical care patients we shall now consider the results of treatment in these patients. Their age and sex distribution is shown in Table IV.

TABLE IV

AGE AND SEX DISTRIBUTION OF MEDICAL CARE CASES

\begin{tabular}{c|c|c|c|c|c|c|c|c}
\hline \multirow{2}{*}{ Year } & Under 30 Yrs. & \multicolumn{2}{c|}{$30-44$ Yrs. } & \multicolumn{2}{c|}{ Over 44 Yrs. } & \multirow{2}{*}{ Total } \\
\cline { 2 - 6 } & Male & Female & Male & Female & Male & Female & \\
\hline $\begin{array}{c}1946-51 \\
1952-55\end{array}$ & 20 & 16 & 18 & 22 & $\begin{array}{c}17 \\
18\end{array}$ & $\begin{array}{c}17 \\
20\end{array}$ & 2 & 94 \\
\hline $\begin{array}{c}\text { Total } \\
(1946-55)\end{array}$ & 35 & 34 & 42 & 35 & 37 & 4 & 187 \\
\hline
\end{tabular}

Medical treatment was conventional; the basic measures were bed rest and, when available, antibacterial drugs.

\section{RESUltS OF TREATMENT}

The results of treatment by medical care instead of by thoracoplasty were assessed by loss of work, sputum conversion, working capacity, and radiographic fate.

(a) Loss of WorK.-The figures presented are aggregates of all periods of loss of work from the time at which the patient was thought to have become suitable for thoracoplasty. The totals of loss of work were classified as less than four months, four to eight months, and greater than eight months. The proportions of patients in these categories were $18 \%, 26 \%$, and $53 \%$ respectively; the duration was not known in $3 \%$ of patients.

Patients under the age of 30 years were off work for the longest periods : $61 \%$ for over eight months, as compared with $44 \%$ of patients aged $30-44$, and $52 \%$ of patients over 45 years old. Only $19 \%$ of patients under 30 years old were off work for less than four months, $23 \%$ of patients aged $30-44$, and $31 \%$ of patients $45-60$ years old.

(b) Sputum Conversion.-As shown in Table $\mathrm{V}, 130$ patients at entry to the series were sputum positive and, of those, 113 became sputum negative. It should be pointed out that the methods of determining sputum state at entry were not strictly comparable with those at final
TABLE V

FATE OF THE 130 PATIENTS INITIALLY SPUTUM POSITIVEד

\begin{tabular}{|c|c|c|c|c|}
\hline \multirow[b]{2}{*}{ Year } & \multirow{2}{*}{$\frac{\text { Initial State }}{\begin{array}{l}\text { Sputum } \\
\text { Positive }\end{array}}$} & \multicolumn{2}{|c|}{ Final State* } & \multirow[b]{2}{*}{ Dead } \\
\hline & & $\begin{array}{l}\text { Sputum } \\
\text { Negative }\end{array}$ & $\begin{array}{l}\text { Sputum } \\
\text { Positive }\end{array}$ & \\
\hline $\begin{array}{l}1946-51 \\
1952-55\end{array}$ & $\begin{array}{l}68 \\
62\end{array}$ & $\begin{array}{l}53(83 \%) \\
60(97 \%)\end{array}$ & $\begin{array}{l}3(4 \cdot 5 \%) \\
1(1.5 \%)\end{array}$ & $\begin{array}{l}8(12 \cdot 5 \%) \\
1(1.5 \%)\end{array}$ \\
\hline Total (1946-55) & 130 & $113(90 \%)$ & $4(3 \cdot 1 \%)$ & $9(6.9 \%)$ \\
\hline
\end{tabular}

* Four unknown in the 1946-51 group. The percentages in this $\omega$ group are calculated for the 64 patients about whom information is available.

assessment. Tests on patients at entry were $\overrightarrow{\vec{A}}$ infrequent and often not confirmed by laryngeal swab, gastric lavage, or sputum culture. Final $\vec{A}$ assessment was by repeated laryngeal swab tests. $ᄋ$ Of the $1946-51$ patients, 68 were sputum positive, and of these 53 became negative at final assess- $\bar{z}$ ment in 1957, eight were dead, and three sputum positive; four patients had left the district and $\stackrel{3}{\partial}$ were well but had not had their sputum tested. $\vec{v}$ Of the 1952-55 patients, 62 were sputum positive at entry and only one did not become sputum: negative. The latter patient had extensive disease. All four of the patients who were sputum positive at final assessment had consistently refused treat-o ment and three were known to excrete drug- $\frac{\varrho}{\infty}$ resistant organisms.

(c) Working CAPACITY. - Although sputum conversion is the most important objective from $\frac{3}{5}$ the point of view of the public health, to the patient the most acceptable benefit is restoration of the ability to resume normal full-time work. $\overrightarrow{0}$ Of the total 187 patients, $149(79 \%)$ were at fulltime work at the conclusion of the study in:December, 1957; proportions for the 1946-513. group of patients and the 1952-55 group were respectively $73 \%$ and $86 \%$.

Working capacity related to sputum state at the time of suitability for thoracoplasty is shown in? Table VI, and it will be seen that the working capacity of sputum-negative patients was good in

TABLE VI

WORKING CAPACITY AT FINAL ASSESSMENT RELATEDC TO SPUTUM AT ENTRY

\begin{tabular}{|c|c|c|c|}
\hline Year & $\begin{array}{l}\text { Sputum } \\
\text { at Entry }\end{array}$ & No. of Cases & $\begin{array}{l}\text { Full-time } \\
\text { Working } \\
\text { Capacity }\end{array}$ \\
\hline $\begin{array}{c}1946-51 \\
1952-55 \\
\text { Total (1946-55) }\end{array}$ & $\begin{array}{l}\text { Positive } \\
\text { Negative } \\
\text { Positive } \\
\text { Negative } \\
\text { Positive } \\
\text { Negative }\end{array}$ & $\begin{array}{r}68 \\
21 \\
62 \\
29 \\
130 \\
50\end{array}$ & $\begin{array}{ll}45 & (66 \%) \\
21 & (100 \%) \\
51 & (82 \%) \\
27 & (93 \%) \\
96 & (74 \%) \\
48 & (96 \%)\end{array}$ \\
\hline Unknown & Unknown & 7 & $7(100 \%)$ \\
\hline Total & . & 187 & $149(79 \%)$ \\
\hline
\end{tabular}


both groups. The results in sputum-positive patients were not similar ; 66\% (45) of the 1946-51 patients were fit for full-time work as compared with $82 \%(51)$ of the $1952-55$ patients. These two figures do not indicate the full value of medical care, since a proportion of the patients, although assessed fit, had refused work and a small number had reached retirement age.

The influence of cavitation upon ultimate capacity to undertake full-time normal work is shown in Table VII. It will be seen that in the 1952-55 group, neither cavitation nor positive sputum significantly affected capacity for work. As would be expected, the results for the 1946-51

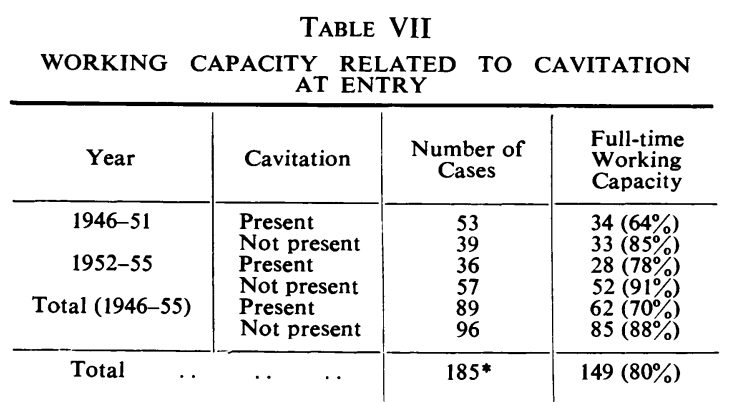

* In two additional cases information about cavitation at entry was not available.
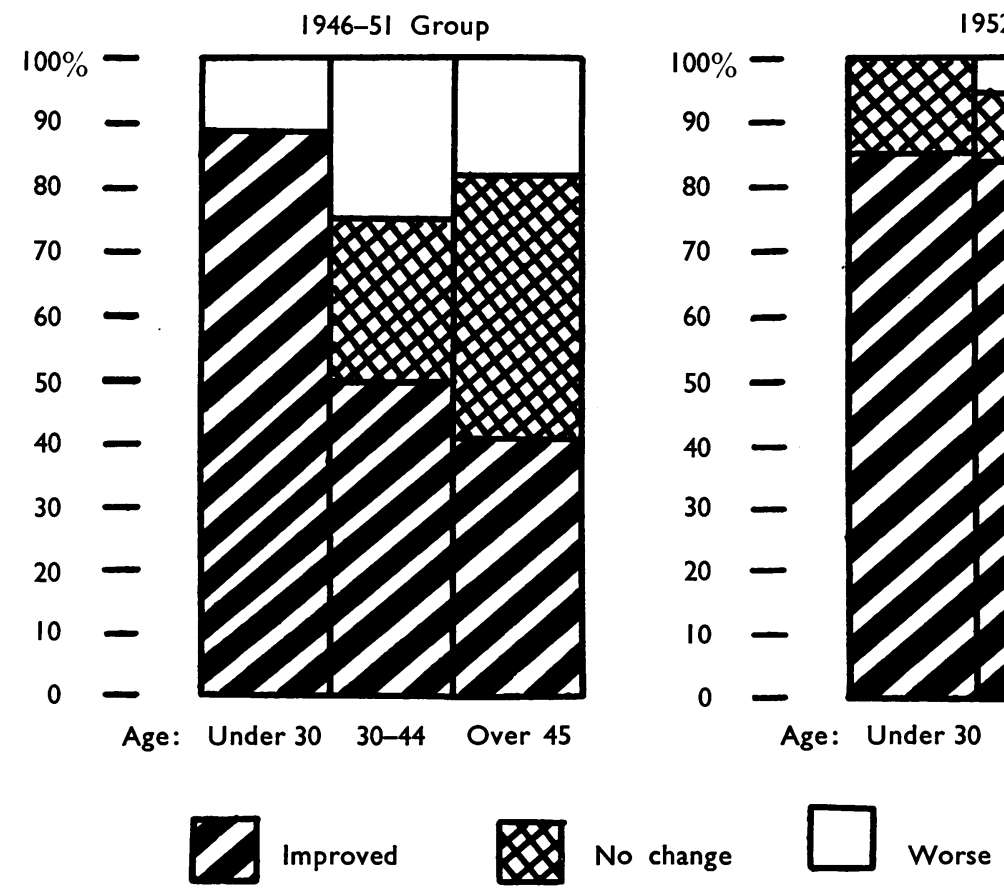

FIG. 1.-Final radiographic assessments, by age groups, of patients treated in 1946-51 and in 1952-55.

TABLE VIII $17 \%$ who deteriorated in the earlier group.

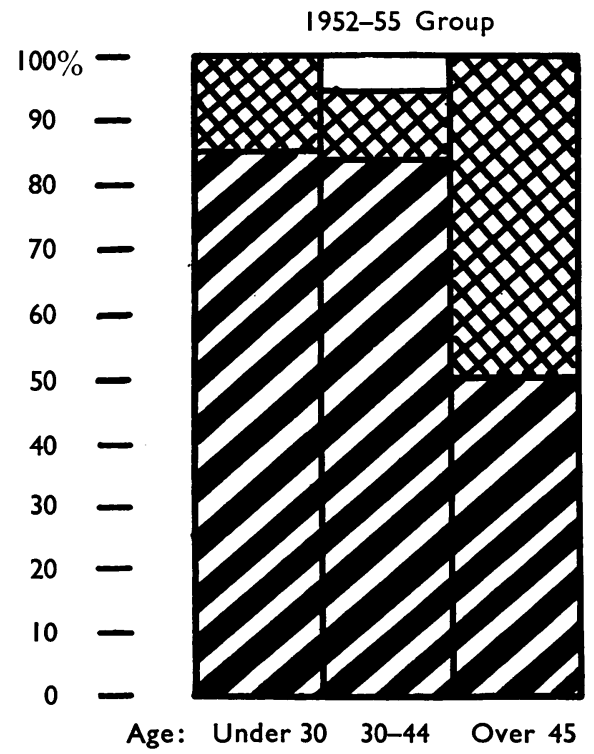

Age: Under $30 \quad 30-44$ Over 45

patients demonstrate that patients with either cavitation or positive sputum did not progress as satisfactorily as the patients without these findings.

(d) Radiographic Assessment. - The final radiographic appearances were compared with those at entry into the study. The cases were divided into three groups: Improved, no change, and worse; the numbers in each category are shown in Table VIII. It is noteworthy that $67 \%$ (125 patients) improved and only $10 \%$ (18 patients)

RADIOGRAPHIC FATE FOLLOWING MEDICAL CARE

\begin{tabular}{c|c|c|c|c|c}
\hline \multirow{2}{*}{ Year } & \multicolumn{4}{|c|}{ Radiological Appearances } & Total \\
\cline { 2 - 5 } & Improved & $\begin{array}{c}\text { No } \\
\text { Change }\end{array}$ & Worse & $\begin{array}{c}\text { Not Re- } \\
\text { corded }\end{array}$ & Total \\
\hline $\begin{array}{c}1946-51 \\
1952-55\end{array}$ & $\begin{array}{l}56(60 \%) \\
69(74 \%)\end{array}$ & $\begin{array}{c}16(17 \%) \\
19(20 \%)\end{array}$ & $\begin{array}{c}16(17 \%) \\
2(2 \cdot 5 \%)\end{array}$ & $\begin{array}{c}6(6 \%) \\
3(3 \cdot 5 \%)\end{array}$ & $\begin{array}{l}94(100 \%) \\
93(100 \%)\end{array}$ \\
\hline $\begin{array}{c}\text { Total } \\
(1946-55)\end{array}$ & $125(67 \%)$ & $35(19 \%)$ & $18(10 \%)$ & $9(4 \%)$ & $187(100 \%)$ \\
\hline
\end{tabular}

deteriorated. Of the patients in the $1952-55$ group $74 \%$ improved and only $2.5 \%$ patients were worse ; the latter figure may be compared with the

The results further subdivided into three age groups are given in Table IX and are illustrated 
TABLE IX

RADIOGRAPHIC FATE RELATED TO AGE

\begin{tabular}{|c|c|c|c|c|c|c|c|c|c|c|c|}
\hline \multirow{3}{*}{ Year } & \multicolumn{9}{|c|}{ Final Radiographic State } & \multirow{3}{*}{$\begin{array}{c}\text { Not } \\
\text { Recorded }\end{array}$} & \multirow{3}{*}{ Total } \\
\hline & \multicolumn{3}{|c|}{ Improved } & \multicolumn{3}{|c|}{ No Change } & \multicolumn{3}{|c|}{ Worse } & & \\
\hline & $\begin{array}{c}\text { Under } \\
30\end{array}$ & $30-44$ & $\begin{array}{l}45 \text { and } \\
\text { Over }\end{array}$ & $\begin{array}{c}\text { Under } \\
\mathbf{3 0}\end{array}$ & $30-44$ & $\begin{array}{l}45 \text { and } \\
\text { Over }\end{array}$ & $\begin{array}{c}\text { Under } \\
30\end{array}$ & $30-44$ & $\begin{array}{l}45 \text { and } \\
\text { Over }\end{array}$ & & \\
\hline $\begin{array}{l}1946-51 \\
1952-55\end{array}$ & $\begin{array}{l}32 \\
28\end{array}$ & $\begin{array}{l}17 \\
31\end{array}$ & $\begin{array}{r}7 \\
10\end{array}$ & $\overline{5}$ & $\begin{array}{l}9 \\
4\end{array}$ & $\begin{array}{r}7 \\
10\end{array}$ & $\frac{4}{-}$ & $\begin{array}{l}9 \\
2\end{array}$ & $\frac{3}{-}$ & $\begin{array}{l}6 \\
3\end{array}$ & $\begin{array}{l}94 \\
93\end{array}$ \\
\hline Total (1946-55) & 60 & 48 & 17 & 5 & 13 & 17 & 4 & 11 & 3 & 9 & 187 \\
\hline
\end{tabular}

in Fig. 1. Three principal points emerge from a study of this figure: patients under 30 years of age progressed equally well both in 1946-51 and in 1952-55; the response to treatment of patients 30-44 years old was considerably better in those for whom chemotherapy was available at the beginning of illness, i.e., the 1952-55 group; and during both periods a substantial proportion of patients over 45 years of age did not progress favourably.

Table $X$ shows the importance of extent of disease in patients radiographically worse at final assessment. In the 1946-51 group patients with

TABLE X

RADIOGRAPHIC DETERIORATION BY EXTENT OF DISEASE AT ENTRY TO SERIES

\begin{tabular}{c|c|c|c|c|c|c}
\hline $\begin{array}{c}\text { Extent of } \\
\text { Disease by } \\
\text { Foster- }\end{array}$ & \multicolumn{2}{|c|}{$1946-51$} & \multicolumn{2}{|c|}{$1952-55$} & \multicolumn{2}{|c}{$1946-55$} \\
\cline { 2 - 5 } $\begin{array}{c}\text { Carter's } \\
\text { Classifi- } \\
\text { cation }\end{array}$ & $\begin{array}{c}\text { No. } \\
\text { of } \\
\text { Patients }\end{array}$ & Worse & $\begin{array}{c}\text { No. } \\
\text { of } \\
\text { Patients }\end{array}$ & Worse & $\begin{array}{c}\text { No. } \\
\text { of } \\
\text { Patients }\end{array}$ & Worse \\
\hline Class I . . & 30 & $6(20 \%)$ & 35 & $1(3 \%$ & 65 & $7(11 \%)$ \\
,. II ... III . . & 54 & $5(9 \%)$ & 44 & $0(0 \%)$ & 98 & $5(5 \%)$ \\
,. & $5(50 \%)$ & 14 & $1(7 \%)$ & 24 & $6(25 \%)$ \\
\hline Total .. & 94 & $16(17 \%)$ & 93 & $2(2 \%)$ & 187 & $18(10 \%)$ \\
\hline
\end{tabular}

Class II disease responded better than those with Class I disease, though the difference was not statistically significant; patients in Class III did not fare well. These results contrast with the 1952-55 group, in which there is no evidence that extent of disease at entry had any effect upon the result.

\section{Influence of ANTIBACterial Drugs}

In the 1946-51 group 50 of the 94 patients received chemotherapy, 29 of these for more than six months. In the $1952-55$ group 83 patients received drugs and 54 of these for longer than six months. A proportion of the patients had more than 12 months' treatment and a few had antibacterial drugs for over two years. There were 36 patients in the early group who did not have drugs and of these 17 did not show radio- graphic improvement. In the 1952-55 group only $\vec{A}$ 11 patients did not have drugs; some of these had refused treatment, none had deteriorated, and $\vec{A}$ three had improved.

Thus, out of a total of 133 patients who had antibacterial drugs, $76 \%$ showed radiographic $\vec{z}$ improvement. These factors are not necessarily interdependent, for, although $82 \%$ of patients who $\frac{\rho}{\supset}$ had had drugs were able to undertake full-time $\vec{\oplus}$ work, $70 \%$ of those patients who did not have drugs were able to undertake full-time work.

\section{RELAPSES}

In the whole series there were 36 relapses $(19 \%)$ as judged by radiographic deterioration, reappearance of tubercle bacilli in the sputum, $\stackrel{\square}{a}$ or death at any time during the period of $\overrightarrow{\overrightarrow{0}}$ observation. At final assessment half of these 3 patients had improved, thus leaving 18 either dead or with worse radiographic appearances. In the early group 28 patients relapsed and in the later group eight patients.

Relapse rates by length of observation period $x$ were calculated for each group by the usual life- $\frac{5}{3}$ table method. Those for the earlier group were all higher than the corresponding rates for the later group ; and, for example, the probabilities of

TABLE XI

PROBABLE EXPLANATION OF DEATHS AND RELAPSES IN 187 PATIENTS RECEIVING MEDICAL CARE

\begin{tabular}{|c|c|c|c|c|}
\hline & & & Deaths & Relapses \\
\hline $\begin{array}{l}\text { Failure of medical } \\
\text { judgment }\end{array}$ & \multicolumn{2}{|l|}{$\begin{array}{ccc}\text { Interpretation of radio- } \\
\text { graph } \ldots & \ldots & \ldots \\
\text { Inadequate or no drugs } \\
\text { Combination of above } \\
\text { factors } . & \ldots & \ldots\end{array}$} & $\begin{array}{l}- \\
-\end{array}$ & $\begin{array}{l}7 \\
3 \\
5\end{array}$ \\
\hline $\begin{array}{l}\text { Failure of response to } \\
\text { conventional therapy }\end{array}$ & $\begin{cases}\text { Before } 1952 & \ldots \\
\text { After } 1952 & \ldots\end{cases}$ & $\begin{array}{l}\cdots \\
\cdots\end{array}$ & 5 & $\begin{array}{l}2 \\
1\end{array}$ \\
\hline \multicolumn{3}{|c|}{ Refused conventional medical treatment .. } & 2 & 6 \\
\hline Non-tuberculous death & $\cdots$ & $\cdots$ & 2 & - \\
\hline \multirow[t]{3}{*}{ Unexplained relapses } & . & . & - & 3 \\
\hline & \multirow{2}{*}{\multicolumn{2}{|c|}{ Totals }} & 9 & 27 \\
\hline & & & \multicolumn{2}{|c|}{36} \\
\hline
\end{tabular}


relapse within three years of entry to the series were respectively $13 \%$ and $6 \%$.

An attempt was made to define the major reason for relapse in each patient, and the results are shown in Table XI. Failure of medical judgment, either by misinterpretation of radiographs during the early part of the treatment, or by inadequate use of available antibacterial drugs, was thought to be an important factor in half the relapses (deaths excluded). Approximately one-quarter of the relapses occurred among patients who had refused treatment. Of patients who entered the series after 1951, only one, who had extensive disease and at first refused treatment, failed to respond to conventional chemotherapy. This patient was the only one to have relapsed whilst receiving chemotherapy.

\section{Final State}

The final radiographic state of the patients is indicated in Table VIII. It was assessed as worse in 18 patients. Half of these were alive with active disease in December, 1957, and the majority of them had refused conventional treatment. The remaining nine were dead, that is, a mortality of $4.8 \%$ in 187 patients. Eight of these deaths were in the 1946-51 group. The single death in the 1952-55 group was from progressive muscular atrophy.

\section{Comparative Results}

Comparison between different published series cannot be more than superficial. We agree with Gough and others (1957) that the results of treatment are not comparable unless the extent and characteristics of disease are specified. Comparison of Tables I, II, and III with those of the above authors will show that our patients had less severe disease. Fewer had bilateral disease $(34 \%$ compared with $58 \%)$, fewer had

TABLE XII

COMPARISON OF MEDICAL CARE WITH THORACOPLASTY AND RESECTION IN TREATMENT OF PULMONARY TUBERCULOSIS

\begin{tabular}{|c|c|c|c|}
\hline State & $\begin{array}{c}\text { Thoraco- } \\
\text { plasty } \\
\text { (Gough } \\
\text { and others, } \\
\text { 1947-49) }\end{array}$ & $\begin{array}{c}\text { Lobectomy } \\
\text { or Segmental } \\
\text { Resection } \\
\text { (Bickford } \\
\text { and others, } \\
1947-51 \text { ) }\end{array}$ & $\begin{array}{l}\text { Medical } \\
\text { Care in } \\
\text { 1946-51 } \\
\text { Group } \\
\text { Only }\end{array}$ \\
\hline $\begin{array}{l}\text { Dead } \\
\text { Relapses (excluding deaths) } \\
\text { Active disease or disabled } \\
\text { (end of observation period) }\end{array}$ & $\begin{array}{l}32(14 \%) \\
29(15 \%) * \\
7(3.0 \%)\end{array}$ & $\begin{array}{l}9(3 \cdot 3 \%) \\
36(13 \cdot 3 \%) \\
14(5 \cdot 2 \%)\end{array}$ & $\begin{array}{l}8(8.5 \%) \\
20(21.3 \%) \\
8(8.5 \%)\end{array}$ \\
\hline Total patients in each series & 231 & 270 & 94 \\
\hline
\end{tabular}

* These relapses were in the 195 patients in whom disease was judged to be quiescent nine months after operation.
Class III disease (11\% compared with $31 \%)$, less had cavitation ( $48 \%$ compared with $84 \%$ ), and fewer had positive sputum. Their patients were operated upon between December, 1947, and December, 1949, and in Table XII their results are compared with those in our 1946-51 group of medical care patients.

Bickford and others (1957) reported 399 cases operated upon between 1947 and April, 1951, and as shown in Table IV of their paper 270 of these cases had either lobectomy or segmental resection, and it is possible that the disease in many of their cases was similar to that in the cases reported in this paper. For comparison their results are also included in Table XII.

\section{Discussion}

Current treatment of pulmonary tuberculosis was recently assessed in America by Rayl and Murphy (1956). In sputum-negative, cavitated disease nine out of 10 doctors in a large-scale jury type of investigation voted for surgical treatment.

In our investigation we found no evidence that the patients submitted to thoracoplasty differed in any important way from those treated medically. Of 259 patients considered at our retrospective survey to have been suitable for thoracoplasty, 72 were submitted to operation, 59 of them within one year of the time at which they were judged to have become suitable for thoracoplasty. Thus, of 187 patients observed for more than one year after they had reached the point of suitability for thoracoplasty, only 13 were submitted to operation. This illustrates the practical value of the policy of observing patients for some time rather than making an early decision to operate.

Although the effects of chemotherapy have been observed for a long time, the ultimate results cannot be predicted. Nevertheless we are impressed by the fact that not one patient in the 1952-55 group has died from tuberculosis. We consider that our results indicate a need for re-appraisal of the indications for surgery in pulmonary tuberculosis.

There are obvious and reasonable social indications for surgical intervention, which will vary with the domicile of the patient and the availability of continuous medical supervision. As shown by Refsum (1951), surgical collapse improves prognosis even in the absence of chemotherapy. From this and the details in Table $\mathrm{X}$ it may be inferred that if patients refuse medical treatment thoracoplasty should be 
advised. If these patients subsequently refuse chemotherapy, their prognosis is improved by operation.

A second factor evident in Table $\mathbf{X}$ is the high proportion of relapses ascribed to errors of judgment, incorrect interpretation of radiographs, or inadequate prescription of antibacterial drugs. These errors could probably be lessened by group discussion and special review of cases once a year.

At the first assessment, three of the four sputumpositive patients were known to excrete drugresistant organisms. The relationship of this finding to the state of disease at the start of chemotherapy was not clear and it may have been more closely related to the two principal explanations for relapse, viz., refusal to accept treatment and errors of radiographic interpretation. We were unable to find other causes for relapse which would enable us to decide, for the future, whether similar cases should have an operation. More evidence is desirable on the ultimate prognosis for patients treated by long-term chemotherapy and on the precise significance of drug resistance in these patients.

\section{SUMMARY}

Patients who were judged to have been at some time suitable for thoracoplasty in an unselected tuberculosis population under treatment between the years 1946 and 1955 were studied. The fate of 187 patients who subsequently did not have an operation is described.

Follow-up extended from two to 11 years and the results of medical supervision without operation were encouraging.

We are indebted to the Birmingham Regional Hospital Board for financial assistance; we would also thank Miss S. Newton and Mrs. M. Sheldon for secretarial help.

\section{REFERENCES}

Bickford, B. J., Edwards, F, Ronald, Esplen, J. R., Gifford, J. H. Thomas, O. F., and Waddington, J. K. B. (1957). Thorax, 12, 152. Foster-Carter, A F. Myers, M Goddard, D L H Young, F. H and Benjamin, B. (1952). Brompton Hosp. Rep., 21, 1.

Gough, J. H., Barlow, D., Sellors, T. Holmes, and Thompson, V. C. (1957). Thorax, 12, 241.

Rayl, John E., and Murphy, James D. (1956). Amer. Rev. Tuberc., 73,191 .

Refsum, E. (1951). Acta tuberc. scand., Suppl. 29.

Singh, M. M., and Smith, J. M. (1957). Tubercle (Lond.), 38, 129.

Thomas, C. Price (1952). In Modern Practice in Tuberculosis, Vol. 2, p. 117, ed. Sellors, T. H., and Livingstone, J. L. Butterworth, London. 